\title{
Die uitbouing van die Bybelse kanon in antieke Judaïsme en die vroeë Christendom
}

\begin{tabular}{|c|c|}
\hline \multicolumn{2}{|l|}{$\begin{array}{l}\text { Author: } \\
\text { Jörg Frey }{ }^{1,2}\end{array}$} \\
\hline \multicolumn{2}{|c|}{$\begin{array}{l}\text { Affiliations: } \\
{ }^{1} \text { Theologische Fakultät, } \\
\text { Universität Zürich, } \\
\text { Switzerland }\end{array}$} \\
\hline \multicolumn{2}{|c|}{$\begin{array}{l}\text { ²Faculty of Theology, } \\
\text { North-West University, } \\
\text { Potchefstroom Campus, } \\
\text { South Africa }\end{array}$} \\
\hline \multicolumn{2}{|c|}{$\begin{array}{l}\text { Note: } \\
\text { The author is Professor of } \\
\text { New Testament Studies at } \\
\text { the University of Zurich, } \\
\text { Switzerland, and Research } \\
\text { Associate of North-West } \\
\text { University, Potchefstroom, } \\
\text { Campus, South Africa. }\end{array}$} \\
\hline \multicolumn{2}{|c|}{$\begin{array}{l}\text { Correspondence to: } \\
\text { Jörg Frey }\end{array}$} \\
\hline \multicolumn{2}{|c|}{$\begin{array}{l}\text { Email: } \\
\text { joerg.frey@theol.uzh.ch }\end{array}$} \\
\hline \multicolumn{2}{|c|}{$\begin{array}{l}\text { Postal address: } \\
\text { Kirchgasse 9, H-8001 Zürich }\end{array}$} \\
\hline \multicolumn{2}{|c|}{$\begin{array}{l}\text { Dates: } \\
\text { Received: } 03 \text { Nov. } 2014 \\
\text { Accepted: } 03 \text { Feb. } 2015 \\
\text { Published: } 31 \text { July } 2015\end{array}$} \\
\hline \multicolumn{2}{|c|}{$\begin{array}{l}\text { How to cite this article: } \\
\text { Frey, J., 2015, 'Die uitbouing } \\
\text { van die Bybelse kanon } \\
\text { in antieke Judaïsme en } \\
\text { die vroeë Christendom', } \\
\text { HTS Teologiese Studies/ } \\
\text { Theological Studies 71(1), } \\
\text { Art. \#2853, } 9 \text { pages. http:// } \\
\text { dx.doi.org/10.4102/hts. } \\
\text { v71i1.2853 }\end{array}$} \\
\hline \multicolumn{2}{|c|}{$\begin{array}{l}\text { Copyright: } \\
\text { (C) 2015. The Authors. } \\
\text { Licensee: AOSIS } \\
\text { OpenJournals. This work is } \\
\text { licensed under the Creative } \\
\text { Commons Attribution } \\
\text { License. }\end{array}$} \\
\hline \multicolumn{2}{|l|}{ Read online: } \\
\hline 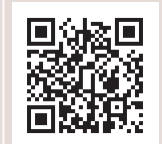 & $\begin{array}{l}\text { Scan this QR } \\
\text { code with your } \\
\text { smart phone or } \\
\text { mobile device } \\
\text { to read online. }\end{array}$ \\
\hline
\end{tabular}

The development of the biblical canon in ancient Judaism and early Christianity. A brief account of the process of the development of both the Jewish and the bipartite Christian canon is given. It is argued that due to insights gained from recent textual discoveries, especially the Dead Sea Scrolls (Qumran texts), earlier theories about the history of canonisation had to be reviewed. With the New Testament canon the authors focus on the influence of Marcion as well as the various other factors that played a role in the process of canonisation. It is shown that canonisation was the result of a complicated and variegated canonical process. But in spite of the problems of the criteria used and other factors involved, the biblical canon is theologically valuable and 'well-chosen'.

\section{Inleiding}

\section{Verskillende kanons vir verskillende belydende groeperinge}

Verskillende Christelike groeperinge verskil oor die aantal en rangskikking van die boeke in die kanon ('die Bybel' - vgl. Frey 2009:1-64). Daar is oor die algemeen konsensus dat die Ou en Nuwe Testament mekaar opvolg. Daar kom egter veral by die omvang van die Ou Testament aansienlike verskille voor. In 'n Lutherse Bybel word die sogenaamde 'Apokriewe' (Judit, Wysheid, Tobias, Sirag, Barug, 1-2 Makkabeërs, Toevoegings tot Ester en Daniël, en die Gebed van Manasse) tussen die Ou en Nuwe Testament aangetref. Dit verteenwoordig boeke wat nie in die kanon van die Hebreeuse Bybel ingesluit is nie, maar wel in die Septuagint (LXX) en die Vulgaat, laasgenoemde in byna dieselfde volgorde. Met die Hervorming het eers Andreas Bodenstein van Karlstadt (De Canonicus Libellus [1520], in Credner 1847:219-412; vgl. Leipoldt 1908:105-107) en daarna veral Martin Luther hierdie geskrifte 'so nicht der Heiligen Schrift gleich gehalten', hoewel hulle dit goed en nuttig gevind het om te lees. ${ }^{1}$ Hierdie afgrensing was nie alleen deur inhoudelike voorbehoude bepaal nie, maar ook omdat daar toe geen oorspronklike Hebreeuse weergawes van hierdie Apokriewe was nie. Vandag weet ons wel van Semitiese weergawes van hierdie geskrifte (in die Cairo Geniza en die Kumranbiblioteek), byvoorbeeld, van die 'Die Boek van Sirag' wat oorspronklik in Hebreeus geskryf is en 'Tobias' in 'n Aramese weergawe. Dit beklemtoon hoe tydgebonde die vroeë besluit van die sinagoge oor wat tot die Hebreeuse kanon sou behoort, was.

Finale uitsluitsel oor dié boeke is nog nie met die Lutherse Reformasie gegee nie, maar in die Gereformeerde tradisie is die Ou Testamentiese Apokriewe in een van hul Belydenisse uitgesluit ${ }^{2}$ - vandaar dat dié boeke glad nie, of net gedeeltelik, in Protestantse uitgawes van die Bybel opgeneem is. ${ }^{3}$ In teenstelling hiermee, is die Vulgaat in 1546 deur die Roomse Tridentium in sy stryd teen die Hervorming as kanonies vasgelê (vgl. Denzinger 2005:1501). In RoomsKatolieke uitgawes van die Bybel word hierdie sogenaamde deuterokanonieke geskrifte dus nie as bylae tot die Ou Testament ingesluit nie, maar saam met die boeke van die geskiedenis, wysheid en die profete geplaas.

Die volgorde van die boeke is betekenisvol omdat dit in die reël nie bloot van historiese aard is nie, maar ook teologiese sienings bevat. Hier onderskei die Hebreeuse Bybel sig van die Griekse Septuagint, wat die basis van die Christelike Bybel in die vroeë kerk geword het. Die Hebreeuse Bybel, die 'Tanak' (Tora, Neviim, Ketuvim), begin met die vyf boeke van Moses (Tora), gevolg deur die reeks van profete (Neviim) wat onderskei tussen wat aanvanklik die 'eerste profete' genoem is en handel oor die geskiedenis van Israel (Josua, Rigters, Samuel en Konings) en dan die 'latere profete,' die 'werklike' profeteboeke van die profete Jesaja, Jeremia,

\footnotetext{
1.Vergelyk Martin Luther se Erläuterung unter dem Stichwort 'Apokryphen' in sy eerste volledige Bybel van 1534.

2.In die Calvinistiese tradisie, in die Confessio Gallicana van 1559 en die Confessio Belgica van 1561, en later ook in die Anglikaanse tradisie.

3.Die Apokriewe is in die eerste volledige Reformatoriese Bybel van 1534 behou (Froschauer Bibel). Die Neue Zürcher Bibel laat dit egter weg.
} 
Esegiël en die Twaalfprofeteboek. Wat hierop volg, is 'n uiteenlopende versameling geskrifte (Ketuvim) met die Psalms, dan die wysheidsboeke Job en Spreuke, dan die vyf feesrolle (Rut, Hooglied, Qohelet = Prediker, Klaagliedere van Jeremia, en Ester), die apokaliptiese boek van Daniël en die laat-historiese boeke van Esra-Nehemia en Kronieke. In teenstelling hiermee het die Septuagint ${ }^{4}$ die Tora waarop die geskiedenisboeke volg (Josua, Rigters, Rut, 1-4 Koninkryke [= 1-2 Samuel 1-2 Konings]) en 1-2 Paraleipomena (1-2 Kronieke ), 2 Esdras (Nehemia-Esra) en Ester, maar ook 'n paar boeke wat eers in Grieks geskryf is, of ten minste nie in die Hebreeuse kanon opgeneem is nie; boeke soos 1 Esdras (= 3 Esraboek), Judit, Tobias en vier Makkabeërboeke. Dan volg ook die wysheidsgeskrifte van die Psalms ${ }^{5}$ en Liedere ${ }^{6}$ oor die Spreuke, Prediker (= Qohelet), Hooglied, Job, Wysheid van Salomo (slegs in Grieks) en die Wysheid van Sirag (= Ecclesiasticus). Aan die einde volg die profetiese boeke, die eerste twaalf profete van Hosea tot Maleagi, dan die groter profete, Jesaja, Jeremia (met Baruch, Klaagliedere en die brief van Jeremia), Esegiël en as slot, Daniël (met sy Griekse toevoegings). Daniël is in die Hebreeuse weergawe onder die wysheid gegroepeer maar hier onder die profete. In die Christelike kanon vorm Daniël weer 'n skakel na die Nuwe Testament. Die eindposisie van die profete dui op 'n oriëntering op die toekoms wat nie in die Hebreeuse kanon so aangebied word nie. Die Septuagint bevat dan ook boeke wat in die Hellenistiese Judaïsme, van die Ptolemeërtyd (aanvang van die derde eeu v.C.) tot die eerste eeu n.C., slegs in Grieks voorgekom het. ${ }^{7}$ Die Latynse Kerk gebruik weer die Vulgaat wat ook weer effens van die Septuagint verskil, byvoorbeeld, enkele boeke soos 3 Esra en 3-4 Makkabeërs is nie deel daarvan nie.

Wat die Nuwe Testament betref, is die inhoud van die boeke dieselfde by Lutherane, Gereformeerdes, Katolieke en Ortodokse groeperinge. Slegs die oud-Oosterse kerke wyk hiervan af: die Oos-Siries-Nestoriaanse kerk erken nie Judas, 2-3 Johannes en 2 Petrus nie en die Etiopiese kerk het 'n omvangryker kanon. Hieraan sal nie verdere aandag gegee word nie.

Die opeenvolging van die boeke in die Nuwe Testament was vir Luther problematies.: In die September-Testament van 1521 (sy eerste weergawe) het hy vier boeke ongenommerd gelaat en aan die einde geplaas, naamlik: die Hebreërbrief, die Jakobusbrief, asook die Judasbrief en die Openbaring van Johannes. Hy het probleme daarmee om die boeke as evangelies en (saaklik) apostolies te beskou. Gevolglik verplaas hy Hebreërs en Jakobus na agter in die lys. In alle Lutheraanse Bybels staan dit steeds op dié plek, wat van ander uitgawes

4.0 ok hier bestaan daar volgens die getuienis van die kerkvaders groot verskille, wat aandui dat die finale begrensing van die kanon nie te vroeg in die vroeë Christendom afgehandel is nie. (vgl. Karrer \& Kraus 2008:8-63).

5.In die LXX het die Psalms verskillende samestellings en daar is ook ' $n$ Psalm 151.

6.Dié boek bevat ook Christelike tekste soos die Magnificat en Benedictus (Luk 1: 46-55, 68-79) in Lied 9. Dit toon aan dat die kanon van die LXX eers in Christelike tye afgesluit is.

7.Oor die datums vir die vertaling van die onderskeie boeke, vergelyk die tabelle deur Dorival, Harl en Munnich (1988:110v.) verskil. Luther was besonder uitgesproke in dié kritiek en nie al sy navolgers het hom hierin gesteun nie. Die volgorde van die res van die boeke was vir hom aanvaarbaar.

Op basis van dié waarnemings moet vervolgens vasgestel word wat bogenoemde kanoniese verskille vir die verskillende Christelike posisies inhou. Vroeër het die Latynse vertaling van die Bybel in die Weste en die Griekse Bybel in die Ooste die omvang van die kanon bepaal sonder direkte kritiese beoordeling deur kerkgroepe. Tog moet daarmee rekening gehou word dat die vroegkerklike beslissings oor die kanon in komplekse historiese prosesse gegrond is wat deur historiese en teologiese waarde-oordele bepaal is. Wie die kanon na waarde wil beoordeel, mag hierdie faktore asook die toevallighede wat daarmee saamhang, nie uit die oog verloor nie.

\section{Die sin en bedoeling van ' $n$ kanon}

Die Griekse woord kanōn ['maatstaf, riglyn'] verwys nes die Semitiese kanōh [riet] na 'n maatstaf. In oordraagbare sin kan dit dan ook na 'lys' of 'tabel' verwys. In die vroeë Christendom word die begrip eerstens gebruik om na die algemene 'Reël van Geloof' of die 'Waarheid' te verwys (regula fidei of regula veritatis), en vanaf die vierde eeu n.C. word die woord kanōn ook ingespan om na sinodale besluite en kerkregtelike canones te verwys. Dit is eers in die tweede helfte van die vierde eeu n.C. dat die term aangewend word om te verwys na 'n lys van geskrifte wat deur die kerk as gesaghebbend erken word. Die bestaan van so 'n lys beteken nog hoegenaamd nie dat almal dit aanvaar het nie. In werklikheid verwys die lys eerder na ' $n$ aanspraak of eis van sommige individue of groepe eerder as die heersende werklikheid in die breë kerk.

In werklikheid was die kanoniseringsproses veel meer kompleks, 'n lang proses waarin sekere boeke deur Christelike groepe byvoorbeeld in die erediens gelees is, wat daartoe gelei het dat hierdie groepe die boeke as gesaghebbend hanteer het. Die kanoniseringsproses het eers 'n noodsaaklikheid geword toe leerstellige krisisse en kontroverse, wat oor 'n lang periode ontwikkel het, so 'n proses genoodsaak het. Vroeëre teorieë het veronderstel dat dié kanoniese grense reeds van vroeg af gefunksioneer het. Die oud-Protestantse ortodoksie het byvoorbeeld geleer dat die kanoniese geskrifte woordeliks en letterlik deur God se Gees geïnspireer is, en dat dit selfs geld vir die Hebreeuse vokaaltekens wat uiteraard eers eeue later by die teks gevoeg is. Alles sou net so, letterlik deur die Gees geïnspireer gewees het wat die boeke van die vroegste tye af gesagvol sou maak. Teorieë wat so 'n kategoriale onderskeid tussen die kanoniese en nie-kanoniese boeke maak, misgis hulle dikwels met die kompleksiteit van die historiese prosesse wat 'n rol gespeel het in die daarstel van die kanon.

Navorsing in resente tye het dié historiese problematiek belig en daarmee die teologiese waarheidsaanspraak van kanoniese boeke geproblematiseer: Dit is vandag byvoorbeeld duidelik 
dat nie alle Nuwe Testamentiese boeke van die vermeende skrywers kom nie (waarskynlik kom die minderheid uit die pen van die vermeende skrywers). Hierdie boeke se 'apostolisiteit' kan dus hoogstens inhoudelik bepaal word. Dieselfde geld vir sommige boeke van die Ou Testament waar antieke literêre konvensies pseudonimiteit anders hanteer, byvoorbeeld, dat 'n boek uit die skool van 'n bepaalde bekende persoon (byvoorbeeld van Pythagoras of Plato se skool) aan die bekende persoon self toegeskryf kon word. So skryf die Jode boeke toe aan Moses en Salomo wat bepaald nie deur hulle self geskryf kon word nie. Dit is ook 'n vraag of Prediker (Qohelet), wat aan Salomo toegedig word, werklik meer vroom of teologies meer waardevol is as die Wysheid van Sirag, of as sommige boeke wat in die Etiopiese kanon opgeneem is, soos die Henogboek. Die Ignatiusbrief is ook saaklik meer inhoudryk as van die kanoniese boeke, soos byvoorbeeld Judas.

Sentrale teologiese vrae ten opsigte van die boeke in die kanon is, of dit primêr oor eksklusief teologiese waarhede gaan en welke gesag daaraan toegeken kan word. Binne die Reformatoriese raam waar gesag slegs aan die Skrif toegeken word, word dié vraag krities belangrik. Omdat die Bybelse geskrifte inherente spanninge en selfs teensprake bevat, kan die vraag egter nie aan die hand van formele maar slegs aan die hand van saaklike kriteria beslis word.

Die historiese vraag is of die 'kanonisering' van hierdie boeke die resultaat is van gesaghebbende uitsprake van biskoppe, sinodes of ander instellings en of die kanoniese boeke eerder op grond van hulle eie inhoudelike gewig in die kanon opgeneem is (vgl. Ritter 1987:93-99). ${ }^{8}$ Kanoniese navorsing neem dikwels nie spesifieke ontwikkelingspunte ernstig genoeg nie. Immers, van die tydstip af dat 'n boek in sekere kringe gesagvol begin raak het, totdat dit saam met ander boeke in 'n lys van kanoniese boeke opgeneem is, veronderstel ' $n$ lang historiese proses waarin vele faktore 'n rol speel - en aan die einde daarvan kan steeds bygevoeg word: Roma locuta - causa finita.

Dié kanoniese prosesse en faktore wat 'n rol gespeel het, kan aan die hand van die volgende verkorte uitbeelding van die Joodse en Christelike kanon verduidelik word. Meer resent ontdekte bronne lei tot nuwe insigte wat ouer klassieke modelle op verskeie punte bevraagteken.

\section{Die Hebreeuse kanon: Van die verklaring van die gesag van die Tora af tot by die rabbynse reëlings rondom die 'verontreiniging van die hande'}

Hoe het die Hebreeuse Bybel (TaNaK) ontstaan? Wanneer is dié kanon 'gevestig' en tot welke mate geld dié kanon vir die outeurs van die Nuwe Testament ook as gesaghebbend?

\footnotetext{
8. Eerstens word hier van ' $n$ kerkkritiese, revisionistiese posisie vertrek wat artikulee dat wanneer nuwe 'apokriewe' boeke gevind sou word, die 'kerk' dit sal verdring of verbied.
}

\section{Die klassieke model van 'n drievoudige kanonisering}

Allereers moet die klassieke idee van die samestelling van die Hebreeuse kanon uitgespel word, om daarna die ontdekkings by die Dooie See te bespreek en te verduidelik hoe hierdie bronne die siening oor kanonvorming beïnvloed. Op die probleme van die oudste Ou Testamentiese literatuurgeskiedenis en vrae oor hoe dit uit bronne, vertaalsiklusse en wetskorpusse tot die Tora en profeteboeke ontwikkel het, word nie hier verder op ingegaan nie (vgl. Schmid 2008; Zenger \& Frevel 2012).

Voorheen het navorsers uit verskeie 'kanongetuienisse' (vgl. Becker 2009:218-253; McDonald \& Sanders 2002:580582 ) 'n drievoudige opeenvolgende outorisering geponeer, eers van die Tora (ongeveer 400 v.C.), daarna van die profete (voor of kort na 200 v.C.) en dan nog later, ná die Tempel se vernietiging in 70 n.C., ook van die geskrifte. Dié siening gaan hoofsaaklik terug op die Joodse geleerde, Heinrich Graetz (1817-1891) (Graetz 1886:281-298). Vir die datum van die afsluiting van die kanon word dan na Nehemia 8 verwys, waar die boek van die Tora (die Pentateug) onder Esra in die openbaar gelees is, wat as 'n gewisse 'outorisering' van die Joodse Wet deur die religieus tolerante Persiese amptenaar verstaan kan word. Dat die Pentateug teen dié tyd prakties reeds afgesluit is, word ook elders duidelik: Die Samaritane wat sedert die Persiese tyd 'n eie ontwikkeling ondergaan het, neem die Pentateug oor, maar nie die profete en geskrifte nie. Sou 'n mens na dié tyd nog wetsbepalings wou kodifiseer, sou dit nuut geskryf moes word, soos dit byvoorbeeld in die Tempelrol by Kumran of in die Jubileesboek gebeur het; dit sou dan bloot as kommentaar op die Tora kon dien.

Die Siragboek (rondom 200 v.C.) bied belangrike getuienis van die kanon-in-wording - die sogenaamde 'Lof aan die Vader' (Sir 49:10) die profete Jesaja, Jeremia, Esegiël en 'Twaalfprofete' word na mekaar genoem. Dit dui daarop dat hierdie boeke reeds op daardie tydstip in dié genoemde volgorde gesirkuleer het en as gesaghebbend geag is. By die Dooie See is Miqzat Ma'asē hat-Torah ['sommige werke van die Tora'] of 4QMMT C 10v. ontdek wat ook as getuienis kan dien, behalwe dat dié teks erg fragmentaries is. In die boek wat in die middel van die tweede eeu v.C. ontstaan het, lees ons: '[Ons het dit gesk]ryf, dat die insig ontstaan het in die Boek Mo[ses en die] Boek[e van die pro]fete en van Da[wid]...' (Qimron \& Strugnell 1994:62v.). Ook hier word die Tora en profeteboeke as afgeslote eenhede beskou, en 'Dawid' kan moontlik as afkorting vir die Psalms dien. Tog word nog nie na die volle groep van geskrifte verwys nie. Meer sekerheid bereik ons eers met die Griekse vertaling van die Siragboek, waar die vertaler, die kleinseun van die skrywer, in 'n voorwoord die drie groepe noem. Die werk dateer uit ongeveer 130 v.C., en verwys na die Wet, profete en 'die oorblywende boeke' (Sirag slegs in die LXX), waarvan die inhoud en omvang op dié stadium nog nie vasgestel is nie. 
Teen die einde van die eerste eeu n.C. verwys die historikus Flavius Josephus in sy boek, Contra Apionem (I 38-40) uitdruklik na die lys van erkende geskrifte:

Want by ons bestaan daar nie ' $n$ aantal boeke wat van mekaar afwyk en mekaar weerspreek nie maar slegs 22 boeke wat die hele tydperk omvat en met reg as geloofwaardig gesien kan word: Hiertoe behoort die vyf boeke van Moses [...] Van die dood van Moses tot by Artaxerxes [...] het die profete ná Moses die gebeure in 13 boeke beskryf. Die oorblywende vier bevat lofliedere oor God en lewensreëls vir die mense. ${ }^{9}$

Iets soortgelyks vind 'n mens rondom 100 n.C. in die apokaliptiese 4 Esraboek wat van 94 boeke vertel waarvan slegs 24 beskikbaar is vir almal om te lees, terwyl die ander 70 boeke ('n simboliese getal) eers in die eindtyd openbaar gemaak sal word. Wat die 22 of 24 boeke omvat, word nie hier duidelik uitgespel nie en hang daarvan af of 1-2 Kronieke, 1-2 Samuel, 1-2 Konings asook Esra-Nehemia elk as een boek of as twee boeke bygetel word. Dit is egter duidelik dat daar nou 'n numeriese begrensing van erkende boeke ontstaan het wat as die kanon van gesaghebbende boeke bekend staan. Die geleentheid wat die begrensing genoodsaak het, is die krisis rondom die Joodse opstand (66-70 n.C.) wat tot die vernietiging van die Tempel gelei het. Die Jode was verplig om hulle godsdiens nou sonder die Tempel te konseptualiseer; immers, sonder die Tempel het die Skrifte en die sinagogeliturgie in fokus gekom. Tussen 70 n.C. en 200 n.C. moes die rabbyne dus belangrike besluite maak.

Die afsluiting van die Hebreeuse kanon word in dié tyd geplaas. Talle oorleweringe in die Misjna en Talmud word aan Joodse geleerdes te Jabne of Jamnia toegeskryf (vgl. Sternberger 1988:163-174). ${ }^{10}$ Die terminologie wat hier ontstaan, dat spesifieke boeke 'die hande reinig' (Misjna, Yad 3:5), toon dat dit 'heilige' boeke is, teenoor profane boeke wat die hande verontreinig. Die lys van geskrifte word ook nou begrens en vasgelê, sodat Hooglied en Qohelet as kanonies geld (vermoedelik omdat albei aan Salomo toegeskryf word en daaraan hulle gesag ontleen), terwyl 'n boek soos Jesus Sirag wie se outeur aan die mense van die tweede eeu v.C. bekend was, nie opgeneem word nie. Dit was duidelik dat die kriterium gegeld het dat net boeke waarvan die (fiktiewe) outeur voor die tyd van Esra (ca. 400 v.C.) geleef het, opgeneem kon word. Jonger boeke het nie vir toegang tot die Hebreeuse kanon gekwalifiseer nie. Dat ' $n$ geskrif soos die apokaliptiese Daniëlboek, wat eers teen 165 v.C. afgesluit is, wel toegang verkry tot die kanon, kan daaraan toegeskryf word dat die Daniëlfiguur vermeend in die Babiloniese ballingskap geleef het. Hoewel die vroeë rabbyne se besprekings oor die grense van die kanon voortgegaan het, het die klassieke Jodedom hulle geskrifte nou as vasgestelde tekste erken. Daar het egter langs dié kanon 'n tweede lys van boeke ontstaan wat as die Misjna en Talmudim bekend staan en wat sou teruggaan op

\section{Vergelyk Becker (2009:241-242)}

10.Daar is lank anachronisties van die Sinode van Jamnia gepraat. Daar was verseker nie so'n sinode nie, maar eerder' $n$ veel langer proses wat oor geslagte gestrek het waarin die vroegrabbynse geleerdes in Jabne ' $n$ rol gespreel het in die bespreking van die omvang van die kanon. die mondelingse Tora (vgl. Misjna, Avot 1:1) wat naas die skriftelike Tora sou ontstaan het.

So ontwikkel die beeld van 'n drievoudige fiksering van die Hebreeuse kanon wat van die bykomstige boeke van die Griekssprekende Jodedom onderskei moet word. Later sou die Christene die Septuaginta intensief benut en in hulle kanon gebruik. Hierdie beeld van die kanonontwikkeling is geloofwaardig. Aandag word nou gegee aan hoe die vondste by die Dooie See die proses van kanonvorming belig.

\section{Insigte as gevolg van teksvondste by die Dooie See}

Die 'biblioteek' wat sedert 1947 by Kumran ontdek is en nou ten volle toeganklik geword het (vgl. Stegemann 2007; VanderKam 1998), bevat reste van ongeveer 900 handskrifte waarvan $200 \mathrm{Ou}$ Testamentiese boeke bevat. Met hierdie vonds het groot getalle Hebreeuse en Aramese oorspronklike tekste uit die tyd tussen die oudste Ou Testamentiese geskrifte (dit is die Daniëlboek uit 165 v.C.) en die Misjna (ongeveer 200 n.C.) bekend geword. So het die Bybelwetenskappe insigte verwerf betreffende die Joodse literatuurproduksie rondom die tussentestamentêre en Nuwe Testamentiese eras, asook in die gebruik en uitleg van die Skrifte, die geskiedenis van literêre Gattungen, die ontwikkeling van motiewe en idees, ensomeer (vgl. Frey 2001:129-208, 2011:225-293). Hier kan slegs die aspekte genoem word wat vir die geskiedenis en ontwikkeling van die kanon van belang is (vgl. Frey 2009: 66-87):

1. Die hele Hebreeuse kanon met uitsondering van Ester is in die biblioteek van Kumran gevind. Die meeste manuskripte is van die Psalms gevind (36 manuskripte); van Deuteronomium is 30 en van Jesaja 21 gevind. Dit impliseer dat sekere geskrifte meer gereeld gelees en gekopieer is - hierdie boeke word ook in die Nuwe Testament die meeste aangehaal. Ander boeke kom slegs in een of twee handskrifte voor, of net in fragmente. Van die Jubileesboek kom 15 manuskripte voor en van die Henogboek 12 Aramese manuskripte (van dele), wat voorheen slegs in Etiopies en enkele Griekse fragmente bekend was. Dit roep die vraag op of laasgenoemde boeke vir die kring wat die biblioteek van Kumran gebruik het, 'n kwasi-kanoniese waarde gehad het. In die raamwerk van die veelvoud en gedifferensieerdheid wat binne die Jodedom rondom hierdie tydperk ${ }^{11}$ bestaan het, word tot die insig gekom dat enkele geskrifte groepspesifieke gesag en betekenis geniet het. So is byvoorbeeld die Makkabeërboeke met hulle tema van lojaliteit aan die Hasmonese koninkryk nie gewild by die Kumrangemeenskap met hulle kritiese ingesteldheid teenoor die Hasmonese koninkryk nie. Omgekeerd geniet Henog en Jubilees - wat 'n 364-dag-sonkalender soos Kumran teenoor díe van die Jerusalemtempel gevolg het - sterk aanhang by Kumran. Ander kringe het skynbaar dié boeke nie baie ernstig bejeën nie. Terwyl sommige Joodse groepe ná 70 n.C. opgehou bestaan het, word talryke geskrifte in hulle

11.Josephus vertel van drie 'skole', te wete die Fariseërs, Sadduseërs en Esseners. Die situasie was waarskynlik veel meer ingewikkeld. 
Hebreeuse vorm nie verder gekopieer nie, terwyl ander slegs in Griekse vorm oorgelewer word, wat dan later deur die Christene oorgeneem is omdat dit in die Septuaginta of 'n ander vertaling (Latyns, Siries, Etiopies of Kerkslawies) beskikbaar was.

2. Die Psalms het uiteraard ' $n$ belangrike rol in die Joodse godsdiens gespeel. Tog varieer die volgorde van die Psalms tussen die onderskeie manuskripte en is daar ook manuskripte met byvoegings: Daar is byvoorbeeld 'n Psalm 151 wat ook aan die Septuaginta bekend was en ander Psalms in die Siriese vertaling, asook Psalms in die Daniëlboek. Dawid word as die skrywer van dié Psalms geïdentifiseer. Dié Psalms is nie deel van die latere Hebreeuse kanon nie. Beteken dit dat die Psalmboek in die Kumrantyd nog nie kanoniese gesag gehad het nie? Die Psalmboek is by Kumran gelees en het liturgies gewig gedra, maar die omvang van die teks was nog nie gefikseer nie. Daar bestaan verskeie kleiner verskille tussen die onderskeie manuskripte. Ook van die Jeremiaboek is by Kumran 'n Hebreeuse Vorlage gekry, 'n korter weergawe wat ook aan die Septuaginta bekend was en wat langs die langer weergawe wat uiteindelik in die Hebreeuse Bybel opgeneem is, bestaan het. Dit laat vrae ontstaan omdat die Kumrangemeenskap duidelik die Profeteboeke as gesaghebbend beskou het, en die profete as geïnspireerde verkondigers van goddelike geheime gesien het.

Hierdie bevindings dwing ons om ons begrip van die kanoniseringsproses aan te pas. Boeke is skynbaar kanonies gesaghebbend geag sonder dat die teksvorm gefikseer is. Verskeie vorms van die teks sou langs mekaar kon bestaan en as 'geïnspireer' geag word, en in die interpretasie daarvan kon met hierdie variante 'gespeel' word. Daar is derhalwe op die stadium nie so iets soos die 'regte' gefikseerde teks nie. Hierin onderskei die antieke Joodse (en vroeg-Christelike) denke sigself van die latere kerkregtelike voorstellings van kanonisiteit en die kanoniseringsproses.

3. Tot op 'n sekere punt kon daar steeds by Kumran (en nie net daar nie) aan die 'heilige boeke' gewerk en verander word. Lank is beweer dat die Tora as heilige verwoording van die wil van God geld. Ten spyte daarvan vind 'n mens by Kumran ook Toramanuskripte met duidelike aanvullings, soos by die Lied van Mirjam wat langer is as wat Eksodus 15 oorlewer. Navorsing is hierdeur in verleentheid gebring en die vraag moes gestel word of die 'Reworked Pentateuch' (4Q158 en 4Q364-367) werklik as 'Bybelse' manuskripte gesien moes word en of dit 'n 'nuwe' werk verteenwoordig. Die fragmente laat ons nie toe om 'n duidelike oordeel te vel nie, maar die groot verskille en die wye benutting van die teks by Kumran laat ten minste ruimte daarvoor dat die Kumrangemeenskap steeds dié teks in kanoniese sin verstaan het. Dit stel die heersende kanonteorieë voor ernstige vrae. Dié waarnemings toon dat in die tyd van Jesus en die vroegste Christene daar nog nie van 'n 'kanon' gepraat kan word in die sin waarin die term later aangewend is nie. Daar bestaan wel heilige, dit is, gesaghebbende geskrifte wat goddelike wysheid en leiding vir die oomblik bevat en waarin 'n mens die geheime van God vir die hede en toekoms kan vind. Daar bestaan ook bykomstige geskrifte wat uit kommentaar op die heilige boeke bestaan, en soms bevat dit byvoegsels tot die heilige boek wat 'n nuwe werk konstitueer (soos in die geval van pseudo-Esegiël, pseudo-Jeremia, ens.). Die begrensing van die lys van boeke wat as 'geïnspireer' geag is, was egter nog nie in die oog nie. Die lys van gesaghebbende boeke is wel gelees en gekopieer maar was nog wyer as die latere Hebreeuse kanon.

4. 'n Laaste bevinding uit die Kumranvondste het navorsing die meeste beïnvloed: Ons het hier vir die eerste keer deur middel van manuskripte insig verkry in die proses van redaksie, versameling, outorisering en benutting van die Skrifte. Dit het navorsers in staat gestel om 'n model van 'kanoniese prosesse' (Sanders 1999:1-22) wat oor jare heen uitdrukking gevind het, te ontwikkel en verskillende fases van outorisering van die onderskeie geskrifte te identifiseer. Die proses het uiteindelik uitgeloop op die daarstel van 'n lys van boeke wat na inhoud en samestelling as gesaghebbend vasgestel is. Dié het daartoe gelei dat hedendaagse navorsers nie fokus op die spesifieke ontstaansaksie van die kanon of wanneer die kanon afgesluit is nie, maar eerder deur aandag te gee aan die langsame en plurale 'kanoniese proses'. Ook hierdie model poneer 'n drievoudige proses van kanonisering, wat die Hebreeuse Bybel se drievoudige indeling in Tora, Neviim en Ketuvim weerspieël. Wat saak maak, is dat die kanonisering nie meer aan 'n sinodebesluit of die besluit van Jabniese geleerdes gekoppel word of aan 'n linêere proses wat doelgerig ingerig is nie. Dit gaan eerder om ' $n$ uitdyende proses wat nie deur ' $n$ instelling uitgevoer is nie; onderskeie en diverse groepe binne die Jodedom het onderskeie boeke benut wat hulle onderskeidelik as gesagvol beskou het. Hierdie onderskeie boeke en tekste het aan die verskillende groepe 'n bepaalde identiteit verleen en hulle deur verskillende krisisse gedra. Dit was een rede waarom die boeke gesaghebbendheid onder die spesifieke groepe verwerf het. In die proses is die tekste toegeëien, aangepas en verder uitgebrei.

\section{Faktore wat in die ontstaan van die Christelike kanon 'n rol gespeel het}

Bogenoemde denkmodel van 'kanoniese prosesse' is nuttig om oor die tweeledige Christelike kanon wat in die vroeë Christelike kerk ontwikkel het, te besin. Die lang en onreglynige ontwikkeling waardeur dié Nuwe Testamentiese dokumente kanoniese gesaghebbendheid verwerf het, veronderstel 'n kanoniseringsproses wat analogies met dié van die Hebreeuse Bybel verloop het.

Teologies is die vraag hier selfs nog dringender, of en hoe ver die Nuwe Testamentiese geskrifte as gevolg van hulle saaklike inhoud en gewig (of deur providentia Dei) aanvaar is en of die keuse van kanoniese geskrifte en die begrensing daarvan aan kerklike inisiatiewe en instansies te danke is. ${ }^{12}$

12.'n Variasie op dié teorie is dat 'n koherente 'redaksie' van die Nuwe Testament aan die einde van die tweede eeu n.C. onderneem is - vergelyk Trobisch (1996). 
Hieroor kan slegs enkele grondliggende perspektiewe belig word.

\section{Marcion as eerste provokasie}

Dat die Christelike Bybel uit twee dele bestaan,'n Ou en Nuwe Testament, is nie 'n gegewendheid nie. Die kerk sou slegs 'Christelike' geskrifte in sy kanon kon opneem. Die geskrifte van Israel het egter van die aanvang van die Christelike kerk af reeds ' $n$ beslissende rol by Jesus se volgelinge gespeel, asook in Paulus se sendinggemeentes. Een van die oudste Christelike belydenisformules (1 Kor 15:3-5a) verwys na Jesus se dood en opstanding 'ooreenkomstig die Skrifte' en heenwysings en aanhalings uit die Ou Testament, in alle boeke van die Nuwe Testament, is van grondliggende legitimerende betekenis. Wanneer die kerk dan 'n polemiese standpunt teenoor die sinagoge inneem, is die plek en status van die 'Ou Verbond'13 vasgelê as 'Heilige Skrifte' wat saam met die nuwe boeke die geloofsbestaan van die kerk verseker. Dit word in die tweede eeu n.C. een van die belangrikste onderskeidingstekens van die Christelike kerk.

Die kerk was deur die optrede van Marcion genoop om dié lys saam te stel. Marcion was 'n heretikus (vgl. Frey 2005: 11-27) wat in 140 v.C. vanuit die noorde van Klein-Asië na Rome gaan en alle Joodse geskrifte verwerp en daarop aandring dat die Christelike geskrifte van alles wat Joods is, gesuiwer moes word. In dié sin kan Marcion as die skepper van die idee van 'n Christelike kanon beskou word (vgl. Campenhausen 1968:174). Marcion is deur sy eksklusiewe beklemtoning van die Pauliniese korpus daartoe gebring om te verklaar dat die God wat deur Jesus verkondig is, nie versoenbaar met die God van die Ou Testament is nie en dat wet en evangelie onversoenbaar teenoor mekaar staan. Daarom bied Marcion 'n 'gesuiwerde' kanon van Paulus se boeke aan, met Galasiërs aan die spits, wat alle vermeende Joodse elemente, verwysings en aanhalings uit die boeke wil weer. Marcion erken ook die Evangelie van Lukas, wat Paulus op sy sendingreise sou begelei het, en hy skep op dié wyse 'n 'klein kanon' met die Lukas-evangelie en tien 'gekorrigeerde' Pauliniese briewe. Dié uitgawe van sy kanon dwing die kerk om te bepaal watter boeke gesaghebbend is, en dit lei tot 'n krisis wat enduit bydra tot die kanonseringsproses. Dat die Paulusbriewe en evangelies wel in die vroeg-Christelike kringe ' $n$ belangrike rol gespeel het, is bekend. Die wesenlike onderskeid met Marcion was gesetel in die vrae na boeke wat in 'n vroeë bron die 'Profete van die Ou Verbond' genoem is, ${ }^{14}$ en of die pluraliteit van evangelies behou moes word.

Die gevolgtrekking is dat die impulse tot kanonuitbouing deur krisisse aangewakker is wat aanvanklik deur Marcion se teologiese verwarring veroorsaak is en daarna deur Montanus se beweging (tweede helfte van die tweede eeu n.C.), en uiteindelik ook deur die opkomende Gnostisisme

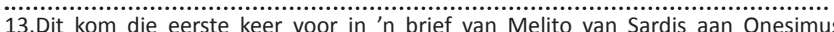
(rondom 170 n.C.) waarin 'n lys van 'Boeke van die Ou Verbond' verskaf word. Vergelyk Eusebius, Historia Ecclesiastica 4, 26. Vergelyk Campenhausen (1968:305-310).

14.Vergelyk Eusebius, ' $\mathrm{n}$ anti-Marcionitiese skrywer wat in 192/3 n.C. werk; Historia Ecclesiastica $\vee 17,2$. verder gestimuleer is. Talle nuwe geskrifte het die lig gesien waaroor die kerk besluite moes neem en waarteen die kerk afgrensings moes doen.

\section{Vroeë omlyning van die versameling van boeke}

Die aanvang van die kanoniese prosesse in die vroegste Christendom het ook vroeër wortels. Marcion gryp terug na 'n versameling van Pauliniese briewe waarvan die Galasiërsbrief een is en wat vir hom die hoogtepunt weerspieël van die onversetlike opposisie tussen wet en evangelie. Marcion se werk toon dat die versameling van Pauliniese briewe vermoedelik die eerste nukleus in die uitbouing van die vroeg-Christelike samestelling van die Skrif gevorm het (vgl. Schnelle 2011:388-403). Die briewe is aan onderskeie gemeentes geadresseer waar dit spesifieke, tydgebonde situasies aangespreek het. Tog het Paulus reeds versoek dat briewe tussen gemeentes in Galasië uitgeruil moes word (Gal 1:2) soos ook in Korinte (2 Kor 1:1). Daarom kan van 'n kern van Pauliniese werke gepraat word wat uit 'n versameling bestaan het en waarskynlik in Efese of Korinte bewaar is. Sedert die einde van die eerste eeu n.C. is die tradisie in na-Pauliniese briewe soos die Efesiërsbrief en die Pastorale briewe, asook die 1 Klemensbrief en Ignatiusbrief voortgesit. Die tweede brief van Petrus wat waarskynlik eers na 130 n.C. ontstaan, beroep sigself dan ook op die briewe van Paulus wat wyd gelees is (2 Pet 3:15v.).

Volgens die oudste manuskripgetuienisse varieer die volgorde van die geskrifte van mekaar. So kom die Romeinebrief saam met die Hebreërbrief, wat lank beskou is as die handewerk van Paulus, en Korintebrief voor (in die Papirus Chester Beatty II, P. 46), terwyl die effe latere lys van die Kanon Muratori 1-2 Korintiërs voor Efesiërs en Filippense plaas; Marcion plaas Galasiërs weer voor Romeine en 1-2 Korintiërs. Dit is egter belangrik om daarvan kennis te neem dat papirusse en perkamentmanuskripte die Pauliniese briewe as 'n samehangende oorleweringskompleks behandel, wat as 'n tweede kompleks naas die vier Evangelies bestaan. Daar was 'n derde deel wat uit die Handelinge en die res van die ('Katolieke') briewe asook 'n kwart van die Johannesapokalips bestaan.

Behalwe vir die Pauliniese briewe verdien die versameling van die Evangelies besondere aandag. Die sogenaamde Logienquelle met woorde van Jesus het hoogstens teen die vyftigerjare ontstaan (vgl. Schnelle 2011:218-238 vir 'n opsomming van die debat). Met die afsterwe van die eerste geslag getuies van Jesus (byvoorbeeld, Petrus, Jakobus, Paulus), ontstaan 'n nuwe impuls om die Evangelie op te teken. Die oudste Evangelie, 'volgens Markus', is vroeër as die weergawe van Petrus se prediking beskou, en daar is sekerlik Petriniese aksente wat in die werk opgemerk kan word. Naas Markus ontstaan dan die twee groot Evangelies, die sterker 'histories'-geïnteresseerde werk van Lukas en die etnies geaksentueerde Evangelie van Matteus. Dit lei daartoe dat Markus se invloed afneem, soos ook in die aantal manuskripte wat van Markus ontdek is, gesien kan word. Die 
Johannesevangelie is duidelik anders as die ander Evangelies en vorm teen 100 n.C. die sluitsteen van die vier Evangelies. Johannes ken wel die ander Evangelies, ten minste vir Markus en Lukas, en hy bied in sy slothoofstuk (21) 'n sintese wanneer die dissipel vir wie Jesus lief was teenoor Petrus gestel word en sy belangrikheid bo Petrus beklemtoon word. Reeds in die eerste helfte van die tweede eeu n.C. (Schultheiss 2012), of op die laatste in die middel van die eeu, word die Johannesevangelie naas die ander Evangelies erken as deel van 'n gerekende versameling en vorm dan ook die basis vir Tatianus se Vier-evangelieharmonie van 170 n.C. sowel as van Irenaeus van Lyons se welsprekende verdediging van die Vier-evangeliekanon in 180 n.C. Ander evangelies wat in die loop van die tweede eeu n.C. ontstaan het, soos die fragmentaries oorgelewerde Petrusevangelie of die Koptiese evangelie van Tomas, was nie konkurrente vir die vier Evangelies nie. Dié evangelies is wel hier en daar gelees en ook gewaardeer, maar dan ook gou weer vergeet (dit geld in besonder die Joods-Christelike evangelietradisies - vgl. Frey 2012:560-660) of beslis verwerp (soos die Tomasevangelie en ander Gnostiese geskrifte).

\section{'n 'Bybelse' aanspraak op individuele geskrifte}

'Kanonisering' is uiteraard ' $n$ resepsieverskynsel. Aan tekste word gesaghebbende status toegeken wanneer mense dit lees, uitbrei en veral wanneer dit as die basis vir die geloof beskou word. 'n Vraag is of sommige geskrifte self reeds 'n implisiete aanspraak of geldigheid besit. As voorbeeld kan die Johannesevangelie dien wat met sy openingswoorde die ander drie Evangelies se begin en selfs die opening van die Skrif (Gen 1:1; LXX) oortref. Daarmee lê dié Evangelie 'n gesagvolle grondslag wat deur die hiperboliese einde in Johannes 21:25 bekragtig word. 'n Verdere aanspraak kom ook by die Johannesapokalips voor met sy afsluitende kanonformule (Op 22:18v.) wat 'n verbod daarop plaas dat enige woorde uit die boek weggeneem of bygevoeg mag word (vgl. ook Dan 4:2; 13:1). Dié voorbeelde toon egter nog nie dat die aanspraak wat 'n boek maak noodwendig veroorsaak dat dit as gesaghebbend aanvaar word nie. Veral oor Openbaring was daar nog 'n lang diskussie in die kerklike Ooste voordat die boek deur hulle as kanonies gesagvol erken is. Die suggestie om gekanoniseer te word kom wel in 2 Petrus voor wanneer dit die moeilik verstaanbare briewe van Paulus aan die gesag van Petrus as ooggetuie ondergeskik maak. So word 'n Pauliniese en Petriniese tradisie teenoor mekaar gestel. Dit het egter relatief lank geduur voordat die bespreking oor en afgrensing van die kanon afgehandel was.

\section{Die bespreking oor die apokriewe evangelies}

'n Verdere vraag handel oor die status van die apokriewe of (beter gestel) apokrief geworde evangelies wat teen die einde van die tweede eeu n.C. bekend was en deur skrywers soos Klemens van Aleksandrië en Origenes aangehaal is. Voorbeelde is die 'Evangelie volgens die Hebreërs' en die 'Evangelie volgens die Egiptenaars', maar ook die Tomasevangelie wat volledig slegs in 'n Koptiese weergawe en op drie papirusse uit die tweede/derde eeu v.C. in Grieks bekend is. Ook die Petrusevangelie is alleen in drie papirusse fragmentaries oorgelewer. Hierdeur word gesuggereer dat ' $n$ groot aantal sodanige werke bestaan het waaruit die kerk 'n keuse gemaak het. Die karakter en aanspraak asook feitelike inhoud en gebruik van onderskeie werke is egter in ag geneem, veral in hoeverre dit getuienis bied van die evangelie. Die vraag is: Is dié geskrifte in eredienste gelees of het dit slegs as opbouende (stigtelike) literatuur gedien? Was dit bedoel om die kanonies geworde evangelies te ondersteun of het dit ' $n$ ander doel gedien?

Leidrade bestaan in die drie weergawes van die Griekse Tomasevangelie (P. Oxyrhynchos I, 645-655) wat in boekvorm bestaan en gebruik in persoonlike of nie-liturgiese situasies (vgl. Lührmann 2004) veronderstel. In hierdie manuskripte is daar geen teken dat hierdie werk enige rol in die erediens gespeel het nie. 'n Ander voorbeeld is die Petrusevangelie, wat as ' $n$ fragment in 'n versameling manuskripte uit 'n Egiptiese graf (P. Cairensis 10759) bekom is. Eusebius (Historia Ecclestiastica 6, 12:1-6) merk op dat die biskop Serapion van Antiochië die lede van die gemeenskap in Rossus se leeslys van werke vir die erediens as toelaatbaar beskou het. Hy keur die gebruik goed sonder om die tekste te ken en ondersoek eers die saak nadat daar twyfel oor die ortodoksie van die gemeente ontstaan. Hierdie voorbeeld illustreer die verskille tussen gemeentes en die relatiewe kennis van 'n biskop, maar ook dat die grense van die kanon eers 'n kwessie word nadat 'n eksterne verleentheid daartoe lei en die gebruik van sulke geskrifte by ander groepe bekend geword het.

Die bevinding is dat ' $\mathrm{n}$ mens nie van 'n 'oorspronklike' gelykwaardigheid van kanoniese boeke kan praat wat teenoor apokriewe boeke gestaan het nie. Dit is eerder 'n geval dat enkele geskrifte duidelik so 'n aanspraak sou kon maak en so benut is. Alhoewel nuwe teksvondste die veelvoud van vroeg-Christelike geskrifte illustreer en ook wys dat tussen die geskrifte duidelike verskille bestaan, bly die aantal ernstige konkurrente vir kanonies geworde boeke klein.

\section{Die broosheid van die kriteria vir en die Griekse toevallighede in die kanoniese proses}

Daar is reeds na probleme met die kriteria wat vir die opname van boeke in die Nuwe Testamentiese kanon aangelê is, verwys. Daar is verwys na ooreenstemming met die regula fidei, die benutting van die boek in die erediens en bo alles, die apostoliese outeurskap van die boek. Maar dié kriteria is nie enkelvoudig of op dieselfde wyse op die onderskeie boeke toegepas nie. Op hierdie basis kan die latere kanonisiteit of nie-kanonisiteit hoogstens gedeeltelik geregverdig word. Daar is in die kanon geskrifte wat geen direkte apostoliese aanspraak het nie, soos die Markus- en Lukasevangelies wat slegs as geskrifte van apostelvolgelinge beskou kan word; die Hebreërbrief, wat aanvanklik as Paulinies beskou is maar later nie meer nie; die Judasbrief, waarvan die veronderstelde afsender interessant genoeg nie 'n apostel was nie maar 'n onbekende broer van Jesus, aangedui as 'broer van Jakobus' 
(Jud 1). ${ }^{15}$ Aan die ander kant is daar boeke wat 'n apostoliese aanspraak maak maar volgens moderne oordeel eerder as pseudoniem geag moet word, wat nie noodwendig impliseer dat die saaklik teologiese gewig daarvan geringer is nie.

Soos by die Hebreeuse kanoniese ontwikkeling moet ook by die Christelike kanoniese ontwikkeling na die onderskeie kanonlyste gekyk word. ${ }^{16}$ Inligting uit dié bron is nie eo ipso so betekenisvol nie. Hierdie lyste wat uit kerklike geskrifte in onderskeie kontekste bekend is, veronderstel 'keine homogene Gattung' nie en is slegs 'aus ihrem jeweiligen Kontext heraus zu verstehen' (Löhr 2005:203). Daarmee moet die onderskeid in die afgrensing van hierdie boeke ernstig geneem word - is 'n bepaalde boek deel van 'n Christelike opbouingsprogram of van Christelike privaatonderrig, of is dit in die erediens of as basis vir die ortodoksie gebruik?

Een van die bekendste dokumente met so 'n lys van boeke is die 'Canon Muratori', ${ }^{17}$ wat rondom 200 n.C. ontstaan en as die oudste getuienis van 'n lys van kanoniese geskrifte erken word. Tog bied dié lys 'gerade keine reine Liste biblischer Bücher', maar 'eher [...] eine ausführliche Einleitung in die [...] reziptierten biblischen Bücher' (Markschies 2007:231) met uitvoerige kommentaar op enkele boeke. Dit kan dus nie in die streng sin van die woord met die latere kanonlyste vergelyk word nie. Aan die einde staan 'n 'ons' wat die perspektief van die ontvangers aandui, waardeur die gerigtheid van die geskrif teen Marcion en die Montaniste gedemonstreer word. Die verwysing dat die 'Herder van Hermas' eers 'neulich und zu unserer Zeit' [nuperrime e[t] temporibus nostris] - (Markschies 2007:232) geskryf is en daarom nie in die openbaar in die kerk gelees mag word nie, verwys na 'n Westerse konteks wat moontlik 'n gemeente binne die stad van Rome kan veronderstel. So bevat die teks 'eine Stück Theologie des "Kanons"' waar na 'institutionellen Kontexten [...] gefragt werden kann' (vgl. Markschies 2007:235). Wanneer 'n teks so gedifferensieerd ondersoek word, kan die geskiedenis van die waarde van die Bybelse kanon meer presies vasgestel word.

Die versameling en kanonisering van die 'Christelike' Bybel het dus deur ' $n$ veelvoud van regionale onderskeidinge en sosiale faktore tot stand gekom. Wat in gedagte gehou moet word, is dat talle gemeentes slegs 'n deel van die latere kanoniese geskrifte tot hulle beskikking gehad het. Die inhoud van die gemeentebiblioteek, veral by armer en kleiner gemeentes, was waarskynlik aan toeval onderwerp. So is daar in die fonds van die Orynhynchos-Papiri van Johannes ses afskrifte gekry, van Matteus vyf en van die Romeinebrief drie, terwyl daar van Markus, 2 Korintiërs, die Efesiërs, Filippense, Kolossense - asook pastorale briewe geen afskrifte voorkom nie. Tog is daar ook fragmente met apokriewe woorde van Jesus gevind, sewe eksemplare van

15.Latere tradisie het Judas verbind met die apostel Judas Taddeus, met die gevolg dat Johann Gottfried Herder die geskrif as apostolies aanvaar (vgl. Frey 2015).

16.Vergelyk die bespreking van dié gegewens by Markschies (2012:1-180).

17.Sien beskrywing by Markschies (2007:330); die teks is vertaal in Markschies (2012:117-120) die 'Herder van Hermas' asook apokriewe Handelinge en Apokalipse en drie eksemplare van die Tomasevangelie (Markschies 2007:315-316). Dieselfde geld ook vir ander oudantieke gemeente- en privaatbiblioteke. Selfs nog belangriker is die heterogeniteit van die opeenvolging van die boeke en hulle vermenging met latere patristiese geskrifte (Markschies 2007:323-324). Dit dui daarop dat 'sich das Konzept eines "Kanons" biblischer Schriften [...] selbst in nachkonstantinischer Zeit noch deutlich von dem unterschied, was die monarchischen Bischöfe und die Synoden normierten [...]' (Markschies 2007:330).

In terme van 'n afsluitingspunt vir die korpus van geskrifte van die $\mathrm{Ou}$ en Nuwe Testament word die eindpunt eers by Athanasius van Aleksandrië geplaas, wat in 350-351 n.C. uit die 'Herder van Hermas' aanhaal, maar byvoeg, dat dit nie 'uit die kanon' kom nie (Athanasius, De Decretis 18, 3). Die opmerking veronderstel dat sekere boeke se gesag toe reeds aanvaar is. Athanasius bied dan ook in sy nege-en-dertigste Paasfeesbrief uit 367 n.C. vir die eerste maal 'n volledige lys van 27 boeke wat die Nuwe Testament vorm (in die volgorde: evangelies - algemene briewe - Paulusbriewe - Openbaring), aan. Dié vierde-eeuse brief word allerweë as die aanduiding van die afsluiting van die Nuwe Testamentiese kanon geag.

Tog vereis ook dié dokument verdere ondersoek. Soos Christoph Markschies aandui, laat die Aleksandrynse patriarg dit duidelik word dat hy die lys van boeke nie eenvoudig ter hand gehad het nie, maar eers die moeite moes doen om dit op te stel. Dit laat die vermoede ontstaan 'dass einfacheren Priestern oder gar Laien der exakte Umfang des Neuen Testaments erst recht nicht bekannt gewesen ist' (Markschies 2007:225-226). En dit gaan in die brief vir Athanasius om iets heel anders, naamlik die toepassing van sy gesag as enigste biskop van die kerk in Aleksandrië ná sy terugkeer uit ballingskap. Sy afbakening toon dat vrye leraars of konkurrente groepe waarskynlik 'einen anderen Begriff von "Kanon" voraussetzen und möglicherweise auch den Umfang heiliger Schriften anders definierten' (Markschies 2007:228). Sy betrokkenheid by die formulering van die kanon van heilige boeke sluit dus ander boeke uit, soos die Henog-, Jesaja- en Mosesgeskrifte. Dit beteken dat ook met hierdie kanonlys wat die huidige Nuwe Testament omvat daar nog geensins 'n einde aan diskussies en besprekings bereik is nie. Selfs al sou die normering vir die Bisantynse Rykskerk gegeld het, het daar in dié kerk steeds hewige diskussies gewoed, oor onder meer, die Johannesapokalips. In groepe wat aan die grense van die ryk gelê het, soos die Nestoriane en Monofisite, was die situasie selfs nog minder geslote. Die Siriese kerk het nog lank die Evangelieharmonie van Tatianus gebruik; in die Oos-Siriese kerk word die Katolieke briewe tot vandag toe nie gebruik nie. Die Etiopiese tradisie het weer 'n eie, unieke en omvangryke kanon ontwikkel wat eers in die veertiende of vyftiende eeu n.C. afgesluit is.

\section{Ten slotte}

Met die afloop van die antieke periode het die tweeledige Christelike kanon, in die Ooste in Grieks en in die Weste 
toenemend in Latyn (Hiëronimus se Vulgaat), feitelik die onomstootlike kanoniese basis geword. Verwysings gedurende die Middeleeue na die Joods-Christelike geskrifte soos die 'Evangelium Herbraeorum' of die 'Evangelium Nazaraeorum' (Frey 2012:589-590) geskied al meer op die basis van 'n werklike kennis van die geskrifte sonder om dit aan die kanon te wil verbind. Ná die afloop van die antieke periode is steeds 'apokriewe' geskrifte geproduseer maar dit kon nie meer die grense van die kanon binnedring of bevraagteken nie. Dat die kerkregtelike besluit oor die omvang van die kanon (die Vulgaat) eers by die Tridentium, as reaksie op die Reformasie se belydenisskrifte, geneem is, onderstreep dat die Middeleeuse teologie minder bepaal is deur die onmiddellike appèl op die skriftelike as deur die komplekse dogmatiese tradisie. Die reformatoriese Sola Scriptura bring verandering - die onderrigformasies word Bybels gegrond en dit het die vraag na die omvang van die kanoniese geskrifte en die saaklike apostolisiteit van die oorgelewerde boeke op nuut gestimuleer.

Moderne navorsing het die ou kriteria vir kanonisiteit van Bybelse boeke in 'n mate gerelativeer. Die apostoliese aanspraak daarvan is histories bevraagteken en die gronde vir die erkenning of afwysing van die kanonisiteit is uitgewys as grootliks afhanklik van historiese omstandighede en politieke konstellasies.

Word die konsep van kanoniese boeke op die manier opgegee of gerelativeer? Die antwoord daarop kan slegs teologies beantwoord word: Ekumenies sou so 'n prysgawe 'n groot verlies wees aangesien die gedeelde kanon een van die sterkste bande is wat die onderskeie Christelike groepe saambind. Saaklik sou oor 'n boek en die waarde daarvan verskil kon word. Wat die totale aantal boeke betref, is ek van mening dat die Nuwe Testamentiese kanon die essensiële en ook historiesoorspronklike Christelike getuienis bewaar. Wanneer dit met die talryke apokriewe boeke vergelyk word, byvoorbeeld die legendariese Apostelhandelinge of die oppervlakkige Evangelietekste soos die Kinderevangelie van Tomas, dan is die kanon steeds 'n goeie keuse wat ten midde van vele omstandighede - error hominum of providentia Deitot stand gekom het. Teologies bied die tweeledige Bybelse kanon iets wesenlik goeds, naamlik die verwysing terug na die oer-Christelike boodskap tot by sy Ou Testamentiese wortels, die geskrifte van Israel wat cum grano salis die 'Bybel' van die oer-Christendom geword het en die blywende verwysingspunt van die Christelike boodskap is.

\section{Erkenning}

Hierdie artikel is vertaal na Afrikaans deur Prof. Jan G. van der Watt.

\section{Mededingende belange}

Die outeur verklaar hiermee dat hy geen finansiële of persoonlike verbintenis het met enige party wat hom nadelig of voordelig kon beïnvloed het in die skryf van hierdie artikel nie.

\section{Literatuurverwysings}

Becker, M., 2009, 'Grenzziehungen des Kanons im frühen Judentum und die Neuschrift der Bibel nach dem 4. Buch Ezra', in M. Becker \& J. Frey (reds.), Qumran und der biblische Kanon, pp. 218-253, Neukirchener Verlag, Neukirchen-Vluyn.

Campenhausen, H. von, 1968, Die Entstehung der christlichen Bibel, Mohr Siebeck, Tübingen.

Credner, K.A., 1847, Zur Geschichte des Kanons, Verlag der Buchhandlung des Waisenhauses, Halle.

Denzinger, H., 2005, Enchiridion symbolorum et definitionum [...], Kompendium der Glaubensbekenntnisse und kirchlichen Lehrentscheidungen, red. P. Hünermann, Herder, Freiburg.

Dorival, G., Harl, M. \& Munnich, O., 1988, La Bible grecque des Septante. Du judaïsme hellénistique au christianisme ancien, Cerf, Paris.

Frey, J., 2001, 'Die Bedeutung der Qumran-Funde für das Verständnis des Neuen Testaments', in M. Fieger, K. Schmid \& P. Schwagmeier(reds.), Qumran - Die Schriftrollen vom Toten Meer, pp. 129-208, Universitätsverlag, Freiburg Schweiz / Vandenhoeck \& Ruprecht, Göttingen.

Frey, J., 2005, ' Marcion', in Klassiker der Theologie: vol 1: Von Tertullian bis Calvin, pp. $11-27$, C. H. Beck, München.

Frey, J., 2009, 'Qumran und der biblische Kanon', in M. Becker \& J. Frey (reds.), Qumran und der biblische Kanon, pp. 1-64, Neukirchener Verlag, Neukirchen-Vluyn.

Frey, J., 2011, 'Die Textfunde von Qumran und die neutestamentliche Wissenschaft. Eine Zwischenbilanz, hermeneutische Überlegungen und Konkretionen zur Jesusüberlieferung', in S. Beyerle \& J. Frey (reds.), Qumran Aktuell: Texte und Themen Jesusüberlieferung', in S. Beyerle \& J. Frey (reds.), Qumran Aktuell: Texte und Themen
der Schriften vom Toten Meer, pp. 225-293, Neukirchener Verlag, Neukirchen-Vluyn.

Frey, J., 2012, 'Die Fragmente judenchristlicher Evangelien', in C. Markschies\& J. Schröter (red.), Antike christliche Apokryphen in deutscher Übersetzung, vol. 1, pp. 560-660, Mohr Siebeck, Tübingen.

Frey, J., 2015, Der Judasbrief. Der zweite Petrusbrief, Evangelische Verlagsanstalt, Leipzig.

Graetz, H., 1886, 'Der Abschluss des Kanons des Alten Testaments und die Differenz von kanonischen und extrakanonischen Büchern nach Josephus und Talmud', Monatsschrift für Geschichte und Wissenschaft des Judentums 35, 281-298.

Karrer, M. \& Kraus, W., 2008, 'Umfang und Text der Septuaginta. Erwägungen nach dem Abschluss der deutschen Übersetzung', in M. Karrer \& W. Kraus (Hrsg.), Die Septuaginta: Texte, Kontexte, Lebenswelten, pp. 8-63, Mohr Siebeck,Tübingen.

Leipoldt, J., 1908, Geschichte des neutestamentlichen Kanons, vol. 2, J.C. Hinrichsche Buchhandlung, Leipzig.

Löhr, W., 2005, 'Norm und Kontext: Kanonslisten der Spätantike', Berliner Theologische Zeitschrift 22, 202-229.

Lührmann, D., 2004, Die apokryph gewordenen Evangelien, Brill, Leiden.

Markschies, C., 2007, Kaiserzeitliche christliche Theologie und ihre Institutionen. Prolegomena zu einer Geschichte der antiken christlichen Theologie, Mohr Siebeck, Tübingen.

Markschies, C., 2012, 'Haupteinleitung', in C. Markschies \& J. Schröter (reds.), Antike christliche Apokryphen in deutscher Übersetzung, vol. 1, pp. 1-180, Mohr Siebeck, Tübingen.

McDonald, L.M. \& Sanders, J.A. (reds.) 2002, The Canon Debate: On the Origins and Formation of the Canon, Hendrickson Publishers, Peabody, MA.

Qimron, E. \& Strugnell, J. (reds.), 1994, Qumran Cave 4 V, Clarendon Press, Oxford. (Discoveries in the Judean Desert, 10).

Ritter, A.M., 1987, 'Die Enstehung des neutestamentlichen Kanons: Selbstdurchsetzung oder autoriatative Entscheidung?', in A. Assman \& J. Assmann (reds.) Kanon und Zensur, pp. 93-99, Fink, München.

Sanders, J.A., 1999, 'The Scrolls and the Canonical process', in P.W. Flint \& J.C. VanderKam (eds.) The Dead Sea Scrolls after fifty years: A comprehensive assessment, vol. 1, pp. 1-22, Brill, Leiden.

Schmid, K., 2008, Literaturgeschichte des Alten Testaments, Wissenschaftliche Buchgesellschaft, Darmstadt.

Schnelle, U., 2011, Einleitung in das Neue Testament, 8. Aufl., Vandenhoeck \& Ruprecht, Göttingen, 388-403.

Schultheiss, T., 2012, Das Petrusbild im Johannesevangelium, Mohr Siebeck, Tübingen.

Stegemann, H., 2007, Qumran, Johannes der Täufer und Jesus, Herder, Freiburg i. Breisgau.

Sternberger, G., 1988, 'Jabne und der Kanon', Jahrbuch für Biblische Theologie 3, 163-174.

Trobisch, D., 1996, Die Endredaktion des Neuen Testaments: Eine Untersuchung zur Entstehung der christlichen Bibel, Universitätsverlag, Freiburg Schweiz.

VanderKam, J.C., 1998, Einführung in die Qumranforschung: Geschichte und Bedeutung der Schriften vom Toten Meer, Vandenhoeck \& Ruprecht, Göttingen.

Zenger, E. \& Frevel, C., 2012, Einleitung in das Alte Testament, 8. Aufl., Kohlhammer, Stuttgart. 